\title{
Marteiliasis affecting cultured mussels Mytilus galloprovincialis of Galicia (NW Spain). I. Etiology, phases of the infection, and temporal and spatial variability in prevalence
}

\author{
Antonio Villalba ${ }^{1}$, Susana G. Mourelle ${ }^{1}$, M. Carmen López ${ }^{1}$, María J. Carballal ${ }^{1}$, \\ Carlos Azevedo ${ }^{2}$ \\ ${ }^{1}$ Center of Marine Research, Ministry of Fisheries and Aquaculture of Galicia, PO Box 208, \\ E-36600 Vilagarcía de Arousa, Spain \\ ${ }^{2}$ Department of Cell Biology, Institute of Biomedical Sciences, University of Oporto, P-4000 Porto, Portugal
}

\begin{abstract}
The histological location, morphological features and ultrastructural characters of the sporulation of the parasite causing Marteiliasis affecting cultured mussels in Galicia fit the characteristics defined for the type species Marteilia refringens. The early stages of the infection are confined to the host stomach epithelium. The spreading of the parasites through the host digestive diverticula involves an exponential increase in the number of parasites as the infection progresses, suggesting the occurrence of merogony, in addition to the well known sporulation. The infection usually triggers a host hemocytic reaction that may slow down or even stop the infection at times. The study of 5 zones of culture disclosed great spatial variability in the prevalence of Marteiliasis on mussels throughout the bays of Galicia, including an area in which no infection was detected. The culture zones located within the bays showed higher prevalences than those located outside. There was no significant difference in the intensity of the infections among the affected zones. Sporulation occurred throughout the year Several peaks of both prevalence and occurrence of heavy infections took place every year. Considering the areas affected by Marteiliasis, the higher the prevalence of the infection the higher the mortality. In some of the studied zones, mortality was significant for the mussel farming industry.
\end{abstract}

\section{INTRODUCTION}

Farming of mussels Mytilus galloprovincialis in the bays of Galicia (NW Spain) is a very important industry for the region. Around $150000 \mathrm{t}$ (wet wt) are produced annually. The techniques and strategies of mussel culture used in this region have been described by Pérez-Camacho et al. (1991). The disease arising from the infection by a Marteilia-like parasite can be considered the most troublesome among those detected in cultured mussels of this region (authors' unpubl. data), because of the well known association of some Marteilia species with massive mortalities of their bivalve host populations (Alderman 1979, Wolf 1979).

The genus Marteilia and its type species $M$. refringens were proposed by Grizel et al. (1974) for a protistan parasite of flat oysters Ostrea edulis affected by 'digestive gland disease' (Comps 1970). Subsequently, several bivalve species infected by parasites of this genus have been reported (Table 1). The epizootiology and temporal cycles of the infections caused by $M$. refringens and $M$. sydneyi in populations of Ostrea edulis in France and Crassostrea commercialis in Australia, respectively, have been documented (Balouet et al. 1979, Wolf 1979, Grizel 1985). The ultra- 
Table 1. Bivalve mollusc hosts of Marteilia spp

\begin{tabular}{|lll|}
\hline Parasite & Host & First citation \\
\hline \multirow{3}{*}{ M. refringens } & Ostrea edulis & Grizel et al. (1974) \\
& Mytilus edulis & Tigé \& Rabouin (1976) \\
& Crassostrea gigas & Cahour (1979) \\
& M. galloprovincialis & Comps \& Joly (1980) \\
& O. chilensis & Grizel et al. (1983) \\
& O. angasi & Bougrier et al. (1986) \\
M. sydneyi & Crassostrea commercialis & Perkins \& Wolf (1976) \\
& C. echinata? & Wolf (1979) \\
M. lengehi & Crassostrea cucullata & Comps (1976) \\
M. maurini & Mytilus galloprovincialis & Comps et al. (1982) \\
& M. edulis & Auffet \& Poder (1985) \\
M. christenseni & Scrobicularia piperata & Comps (1985) \\
Marteilia sp. & Cerastoderma edule & Comps et al. (1975) \\
& Mytilus edulis & Comps et al. (1975) \\
& Venerupis pullastra & Poder et al. (1983) \\
& V. rhomboides & Poder et al. (1983) \\
& Modiolus modiolus & Auffret \& Poder (1985) \\
& & \\
\hline
\end{tabular}

(ca $2 \mathrm{~cm}$ in length) from natural recruitment on coastal rocks, was tied on ropes hung from the rafts, between late February and May 1988 (date depending on site). The seed used in Zones 2 and 3 came from the same batch. Seed sources were different for the other 3 zones. Thinning out the culture ropes and transferring mussels onto new ropes was carried out in the period August-September 1988. The raft initially chosen at Vigo Bay had to be abandoned after 7 mo. Thus another experimental culture was started in Zone 1 when culture ropes were thinned. Cultures were terminated when market size (around $7 \mathrm{~cm}$ in the longest axis) was exceeded in each zone, between August and September 1989.

Samples of 30 mnussels were taken monthly from each experimental site. An approximately $5 \mathrm{~mm}$ thick section of meat containing gills and visceral mass was excised from every sampled specimen, fixed in Davidson's

structure of the sporulation of both species of Marteilia has been described (Perkins 1976, Perkins \& Wolf 1976). Based on the characteristics of the sporogonia, this genus is included in the phylum Paramyxea (Desportes \& Perkins 1990).

Gutiérrez $(1977 \mathrm{a}, \mathrm{b})$ reported the occurrence of Marteilia refringens in oysters and mussels cultivated in the bays of Galicia, based on light microscopy observations. Subsequently Comps et al. (1982) described the new species Marteilia maurini, with Mytilus galloprovincialis as type host, based on host specificity and ultrastructural features. Thus, the specific identity of the parasite causing Marteiliasis in mussels cultivated in Galicia became controversial (Figueras et al. 1991).

The objectives of this study were to determine the identity of the Marteilia-like parasite affecting the mussel Mytilus galloprovincialis of Galicia; to understand the phases of progression of the infection in mussel tissues; to evaluate the prevalence and intensity of the infection and its temporal cycle in different zones of mussel culture in the region; and to assess whether this disease is a serious threat to the mussel farming industry

\section{MATERIALS AND METHODS}

Experimental cultures and sampling of mussels. Experimental cultures were established in floating rafts in 5 zones of mussel cultivation (Fig. 1), following the local culture practices (Pérez-Camacho et al. 1991). The rafts used for the experiments were simultaneously used for commercial cultivation. Mussel seed solution and embedded; $6 \mu \mathrm{m}$ thick sections were stained with Harris' hematoxylin and eosin (H\&E) and examined under light microscopy for disease diagno. sis. In addition, some infected mussels were processed for electron microscopy: small fragments of digestive gland were fixed in $2.5 \%$ glutaraldehyde in $0.2 \mathrm{M}$ sodium cacodylate buffer, pH 7.8 for 2 h at $4{ }^{\circ} \mathrm{C}$, washed in the same buffer and postfixed in buffered $2 \% \mathrm{OsO}_{4}$ for 2 h at $4{ }^{\circ} \mathrm{C}$. After dehydration in an ethanol series, the material was embedded in Epon, sectioned, double stained with uranyl acetate and lead citrate, and observed in a JEOL 100 CXII transmission electron microscope operated at $60 \mathrm{kV}$.

Rating of infection intensity. Each sampled mussel was rated according to the degree of proliferation of

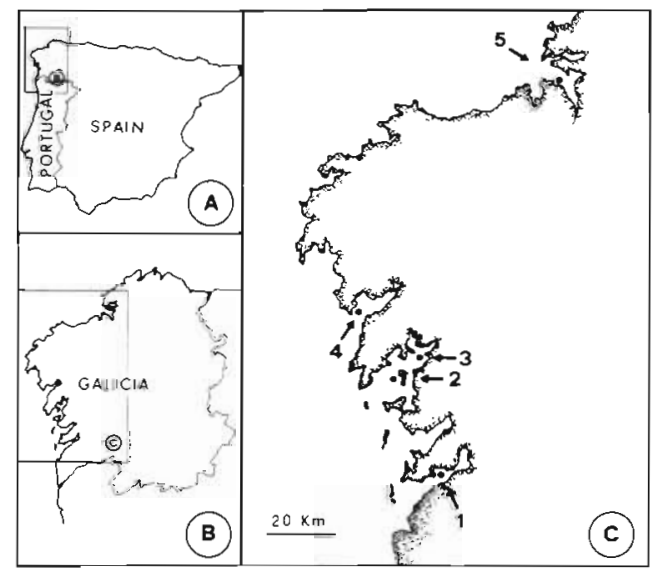

Fig. 1. Location of the experimental cultures ( $)$ in the bays of Galicia. Zone 1 is located in Vigo Bay, Zones 2 \& 3 in Arousa Bay, Zone 4 in Muros Bay and Zone 5 in Ares-Betanzos Bay 
the Marteilia-like parasite, using a scale based on the intensity of infection:

- Uninfected: no parasite detected. Intensity $=0$.

- Light infection: the parasites were confined to the stomach epithelium. Intensity $=1$.

- Moderate infection: just a few digestive tubules (DT) were infected (less than $10 \%$ of the DT visible in a histological section). Intensity $=2$.

- Heavy infection: three different intensity degrees were considered in this category, according to the percentage of infected digestive tubules (PIDT): Intensity $=3$ when $10 \%<$ PIDT $<50 \%$; Intensity $=4$ when $50 \%<$ PIDT $<90 \%$ and Intensity $=5$ when PIDT $>90 \%$.

Each mussel was scored by examining a single histological section. The PIDT was estimated by counting infected and uninfected DT in each of 10 randomly selected microscope fields, at $400 \times$, and then calculating the mean value. A test was made to compare intensity rates estimated from different digestive gland areas of mussels. ( $n=104$ ) mussels coming from the most infected experimental site (Zone 3) were used in this trial. The whole digestive gland of each mussel was transversely sectioned into 3 fragments (anterior, intermediate and posterior) that were processed for histology; a histological section of each of the 3 digestive gland levels per mussel was examined for intensity rating A G-test for independence (Sokal \& Rohlf 1981) showed that the differences between intensity rates estimated from the different levels of the digestive gland were not significant (Table 2). In mussels with heavy infections, a 2-way ANOVA test was performed to compare the PIDT values obtained from the 3 digestive gland levels of each mussel, using a randomized complete blocks design (Steel \& Torrie 1980). Mussels were considered as blocks. Ten observations (10 microscope fields) were made per treatment per block. The PIDT values were arcsine transformed to normalize the data. Differences due to digestive gland levels were not significant (Table 3).

The relative occurrence of each of 3 different stages of the parasite was also estimated for each mussel with

Table 2. Mytilus galloprovincialis infected by Marteilia refringens. Results of a G-test to determine whether estimates of intensity of infection differ according to the level of mussel digestive gland from which they are obtained. $n=104$, $\mathrm{df}=10, G=3.17, \mathrm{p}>0.975$

\begin{tabular}{|lcccccc|}
\hline \multirow{2}{*}{$\begin{array}{l}\text { Digestive gland } \\
\text { level }\end{array}$} & \multicolumn{6}{c|}{ Infection intensity categories } \\
& 0 & 1 & 2 & 3 & 4 & 5 \\
\hline Anterior & 63 & 27 & 6 & 1 & 4 & 3 \\
Intermediate & 61 & 29 & 4 & 3 & 3 & 4 \\
Posterior & 61 & 28 & 7 & 3 & 2 & 3 \\
\hline
\end{tabular}

Table 3. Mytilus galloprovincialis infected by Marteilia refringens. Results of the ANOVA by randomized complete blocks design to compare the estimates of percentage of infected digestive tubules obtained from 3 different levels of mussel digestive gland. ns: $\mathrm{p}>0.05$

\begin{tabular}{|lrcc|}
\hline Source of variation & df & MS & F-value \\
\hline Digestive gland levels & 2 & 0.501 & 0.831 ns \\
Blocks & 7 & 3.543 & \\
Experimental error & 14 & 0.603 & \\
Sampling error & 216 & 0.122 & \\
Total & 239 & & \\
\hline
\end{tabular}

a moderate or heavy infection. The stages considered were 'pseudoplasmodia' including only secondary cells (early stages of sporulation, ES); 'pseudoplasmodia' with secondary cells which included spore primordia (intermediate stages of sporulation, IS); and 'pseudoplasmodia' with refringent granules inside the secondary cells (advanced stages of sporulation, AS). The percentages of parasites corresponding to each stage (PES, PIS, and PAS, respectively) were calculated from each of 10 randomly selected infected DT of an histological section, and a mean value was obtained for each stage. Only sections of infected DT with a visible lumen were examined. Likewise, the mean number of parasites per section of infected digestive tubule (MNPIDT) was estimated from the same selected DT.

Rating of host hemocytic reaction. Each sampled mussel was scored using arbitrary scales for both intensity of hemocytic infiltration of tissues and spreading of granulocytomas, by examination of a single histological section. Both scales ranged from 0 (no infiltration and no granulocytoma, respectively) to 3 (heavy hemocytic infiltration and granulocytomas widespread throughout the digestive gland, respectively), with the scores 1 and 2 as intermediate levels.

Estimation of mortality. For this purpose, and to avoid losses by predation, a batch of 1000 mussels from each experimental culture was placed into circular plastic trays (100 mussels per tray), which were stacked and hung from the rafts. Because of accidental losses of the trays (storms or theft), recording of mortality could not be started until late November 1988 at Zones 1, 2, 3 and 4, and late January 1989 at Zone 5. Live and dead mussels were counted each time when sampling for histology. The death rates calculated for the periods between sampling dates were used to estimate cumulative mortality percentages.

Statistical analysis. Spearman rank correlation coefficients between PIDT and each of the following variables: MNPIDT, PES, PIS, and PAS, were calculated using SOLO statistical software. Association of intensity of infection with intensity of hemocytic infiltration 
on the one hand, and with degree of spreading of granulocytomas on the other hand, was assessed by $G$ tests of independence (Sokal \& Rohlf 1981). The differences in parasite prevalence, intensity of infection and mussel mortality among the culture zones were analyzed by $G$-tests of independence with contingency tables. For prevalence comparisons, the contingency table columns were the numbers of infected and uninfected mussels; for infection intensity comparisons one column was the sum of the number of moderate and heavy infections and the other column was the number of light infections; for mortality comparisons, the columns were the number of live and dead mussels in the trays, after 9 mo in the trays. Table rows were the culture zones.

\section{RESULTS}

\section{Description of the parasite}

The different stages characterizing the life cycle of the genus Marteilia were found in histological sections of the mussels (Figs. 2 to 11). Early stages consisted of multinucleate, spheric to elongated cells, up to $12 \mu \mathrm{m}$ in length (Figs. $2 \& 3$ ). The sporulation process yielded 'pseudoplasmodia' (primary cells) up to $25 \mu \mathrm{m}$ long, enclosing 8 sporonts (secondary cells). Each sporont (ca $12 \mu \mathrm{m}$ in diameter) enclosed 4 spores (tertiary cells). As spores developed, 3 to 7 highly refringent bodies within the sporonts became prominent.

Ultrastructurally, the primary cells were delimited by a plasmalemma. The cytoplasm contained numerous ribosomes and large multivesicular bodies. Free vermiform or oblate haplosporosomes, 30 to $60 \mathrm{~nm}$ in diameter and up to $600 \mathrm{~nm}$ long were found in the cytoplasm. Primary cells also contained striated inclusions 0.5 to $5 \mu \mathrm{m}$ long consisting of membranes of endoplasmic reticulum (ER) cisternae alternating with electrondense zones in periodic array (23.5 nm periodicity). A small number of vesicular mitochondria containing few cristae were also observed (Fig. 8).

Initially, the sporonts (sporont primordia at that moment) were delimited by 2 parallel membranes. The cytoplasm lacked multivesicular bodies, haplosporosomes and striated inclusions; only mitochondria, ER cisternae and numerous ribosomes were included. As sporulation progressed, a wall 23 to $60 \mathrm{~nm}$ thick was formed around each developing sporont. The cytoplasm became progressively vacuolated, and included polymorphic inclusion bodies 2 to $6 \mu \mathrm{m}$ long. These inclusion bodies corresponded to the refringent bodies observed under light microscopy (Fig. 9).

Spores were spheroidal with greatest diameter 3.5 to $5.0 \mu \mathrm{m}$. The protoplasm of each spore consisted of 3 uninucleate sporoplasms of graded sizes, one within the other (Fig. 10). The outermost sporoplasm contained haplosporosomes. These haplosporosomes were mostly spheroidal to oblate, some of them elongated, 92 to $312 \mathrm{~nm}$ long and diameters of 40 to $150 \mathrm{~nm}$. Other cytoplasmic organelles were vesicular mitochondria, vesicles, ER, and ribosomes. As spores matured, the number of haplosporosomes increased and the occurrence of other organelles was progressively reduced. A wall 22 to $30 \mathrm{~nm}$ thick was formed around the outermost sporoplasm. A layer of concentric membranes up to $215 \mathrm{~nm}$ thick was observed surrounding the wall of some mature spores (Fig. 11). The intermediate sporoplasm lacked haplosporosomes similar to those of the outermost sporoplasm, but included flattened, vermiform, double membrane-limited vesicles 180 to $637 \mathrm{~nm}$ long and 23 to $50 \mathrm{~nm}$ diameter, with enlarged ends. In addition, vesicular mitochondria, ER vesicles and numerous free ribosomes occurred in the cytoplasm. The innermost sporoplasm included only 1 nucleus 1 to 2 mitochondria and a high density of ribosomes.

Occasionally, either sporulated or presporulated forms of a microsporidian-like hyperparasite were observed inside the Marteilia-like parasite, under light microscopy (Fig. 6). The hyperparasite was not detected in any ultrathin section.

\section{Progression of the infection in the host}

The vegetative stages were initially seen in the apical border of the stomach epithelium, at the earliest stage of the disease (Figs. 2 \& 3). The infection then spread through the epithelia of digestive diverticula (Figs. 4 \& 5). Sporulation took place mostly in the epithelia of digestive tubules, also in ducts, and very rarely in the stomach epithelium. Sporonts enclosing

Figs. 2 to 7. Marteilia refringens infecting Mytilus galloprovincialis. LM, H\&E staining. Fig. 2. Early stages of the parasite (arrows) in the apical border of the stomach epithelium (*) of the host. L: Lumen of the stomach. $\times 500$. Fig. 3. Detail of early stages of the parasite in the apical border of the stomach epithelium (*). L: Lumen of the stomach. $\times 1250$. Fig. 4. Numerous parasites (arrows) in the epithelium of digestive tubules of the host at a widespread stage of the infection. L: Lumen of digestive tubules. $\times 500$. Fig. 5. Detail of a digestive tubule of the host with advanced stages (arrows) and early stages (arrow heads) of sporulation of the parasite. L: Lumen of the tubule. $\times 1250$. Fig. 6 . Detail of a digestive tubule of the host with early (arrow head) and advanced (arrow) stages of sporulation of $M$. refringens and a pseudoplasmodia of $M$. refringens containing hyperparasite cells (double arrow). L: Lumen of the tubule. $\times 1250$. Fig. 7 . Heavy hemocytic infiltration of an area of the digestive gland of the host infected by the parasite (arrows). The outline of a destroyed digestive tubule (*) can be observed. $\times 500$ 

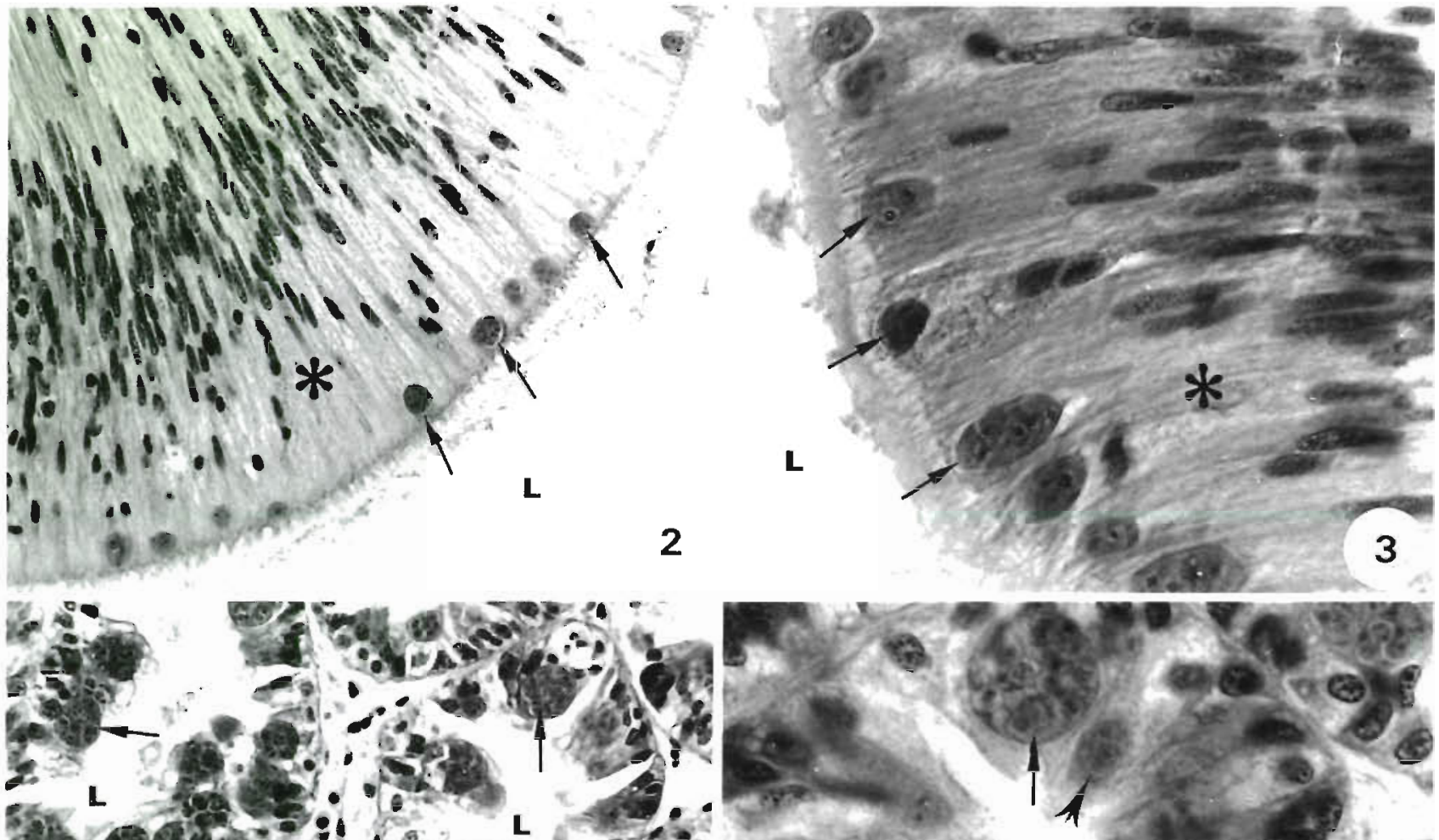

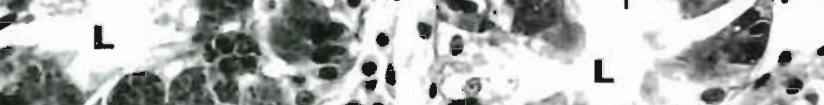

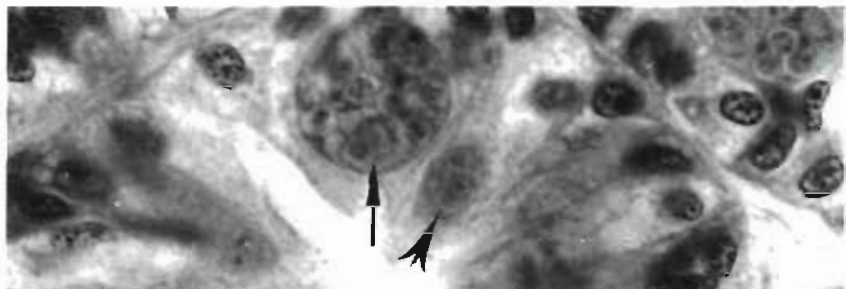

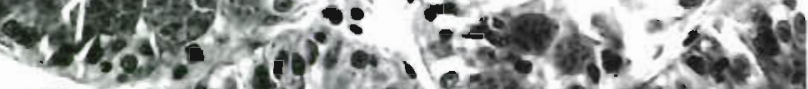

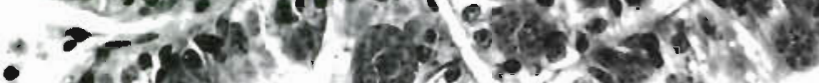
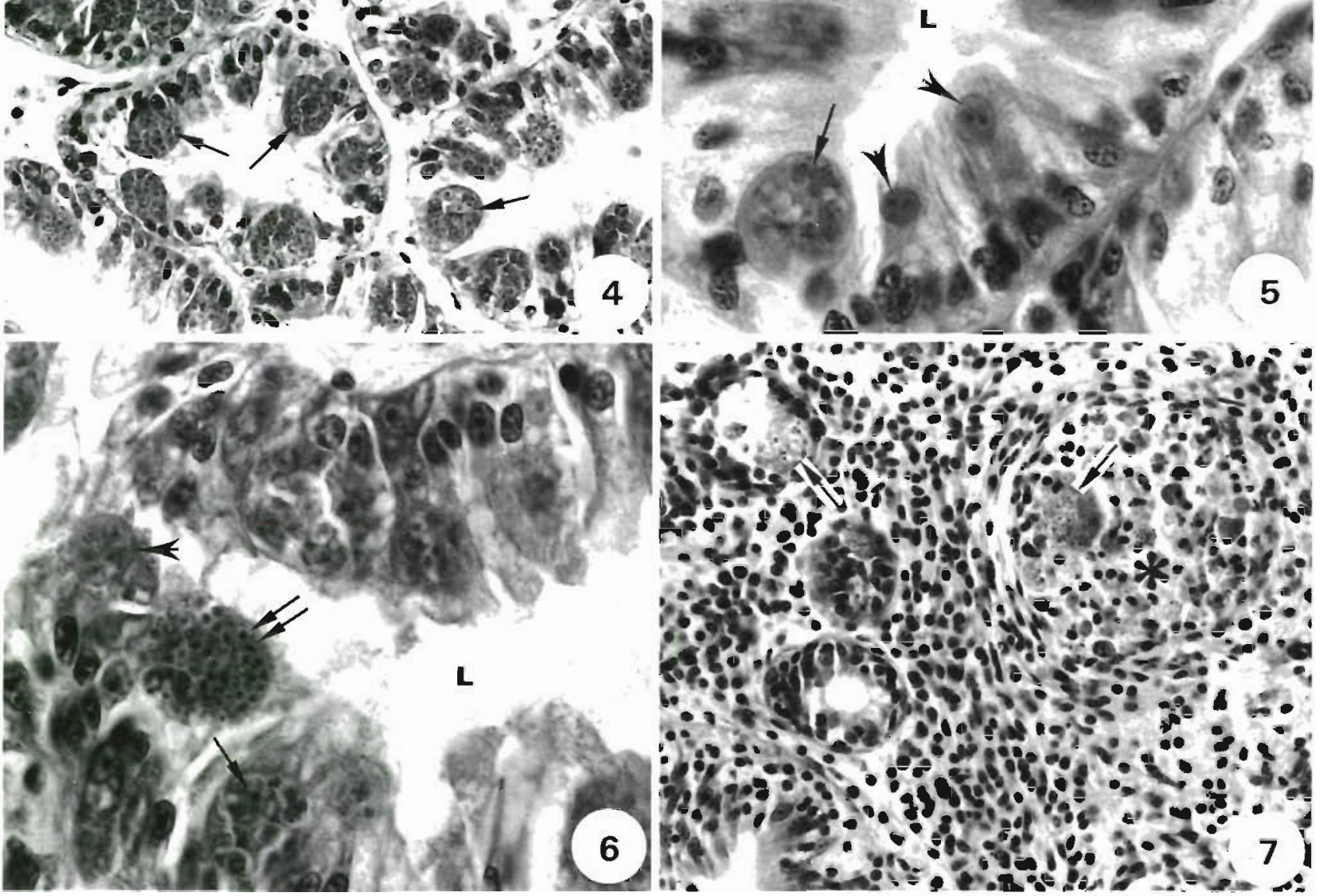


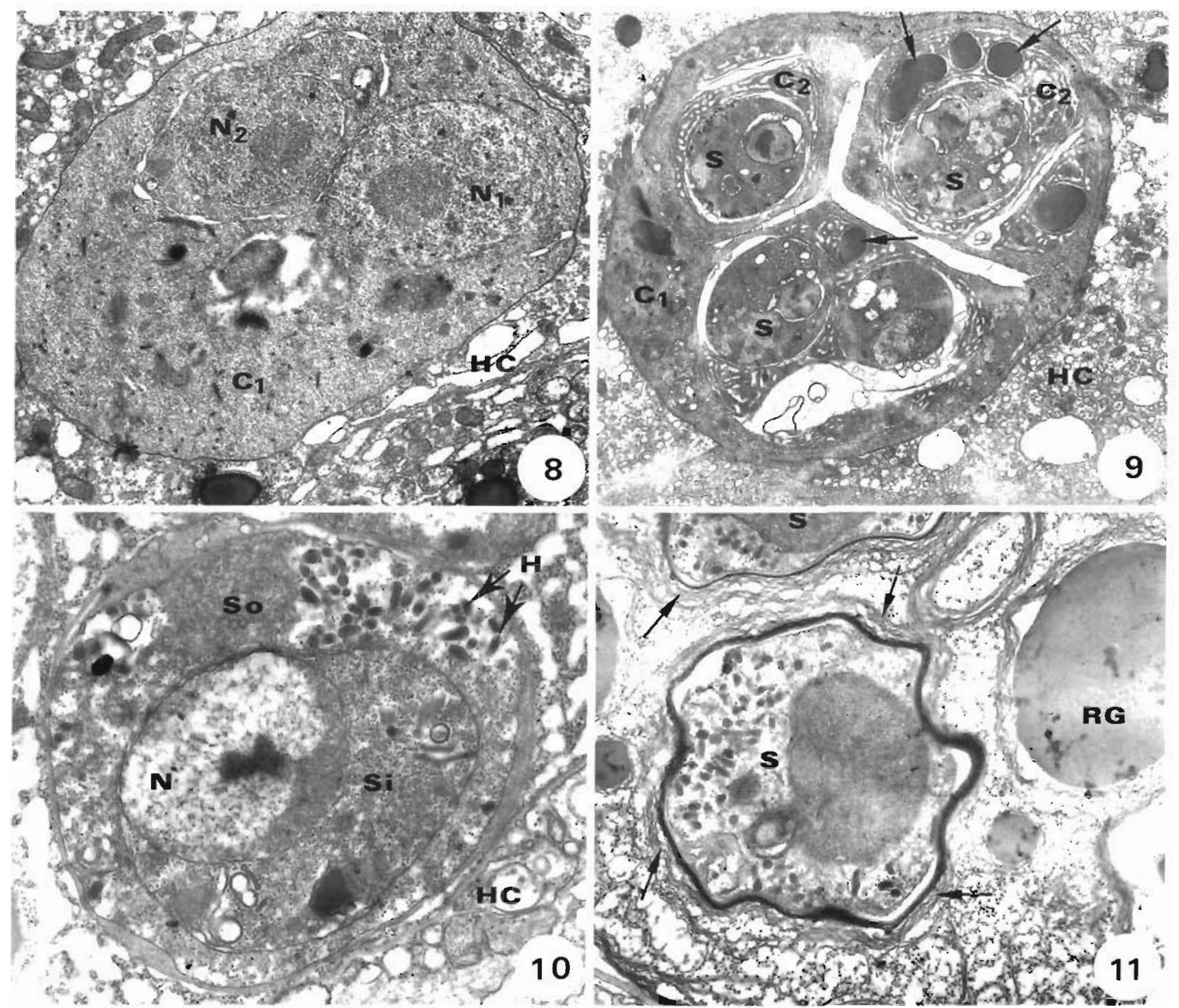

Figs 8 to 11 Martella refringens infecting Mytilus galloprovincialis EM Fig 8 . Early stage of $M$. refringens. $C_{1}:$ Primary cell $N_{1}$ : nucleus of the primary cell, $\mathrm{N}_{2}$ : nucleus of a secondary cell, $\mathrm{HC}$ cell of the host $\times 8000 \mathrm{Fig}$. 9. 'Pseudoplasmodia' of $\mathrm{M}$. refringens Three sporonts $\left(C_{2}\right)$ are observed inside the primary cell $\left(C_{1}\right)$ Spores $(S)$ are included inside the sporonts. Polymorphic inclusion bodies (arrows) can be observed in the vacuolated cytoplasm of the sporonts. $\times 5000$. Fig. 10 . Maturing spore of the parasite in which outermost sporoplasm (So), intermediate sporoplasm (Si) and nucleus ( $N$ ) of the innermost sporoplasm are visible. $\mathrm{H}$ Haplosporosomes, HC cell of the host $\times 20000$ Fig. 11. Mature spore (S) of the parasite showing a layer of concentric membranes (arrows) around wall RG. Polymorphx inclusion body (refringent granule) $\times 15000$

mature spores were released to digestıve lumina, and even partially filled the lumina of the stomach and the intestune in some cases of heavy infection. A variable number of vegetative stages was always seen in the stomach epithelium of infected mussels.

Fig. 12 shows the relationship among the varables typifying the pattern of progression of the infection. The progression was quantifled by the PIDT. The MNPIDT became higher as the infection spread. The PAS tended to increase steadily as the PIDT increased. The PES decreased as the infection progressed, but never reached zero, and even when the PIDT reached the highest values, the PES was around $30 \%$. The PIS increased during the early steps of progression, and plateaued when the PIDT reached 20 to $40 \%$.

The host reaction consisted of hemocytic infiltration of the connective tissue in the digestive gland as well as the epithelia of the stomach and digestive diverticula. This reaction occasionally resulted in facal, massive concentrations of hemocytes (granulocytomas) involving the destruction of both the parasites and the host tissues included in those foci (Fig. 7). G-tests 

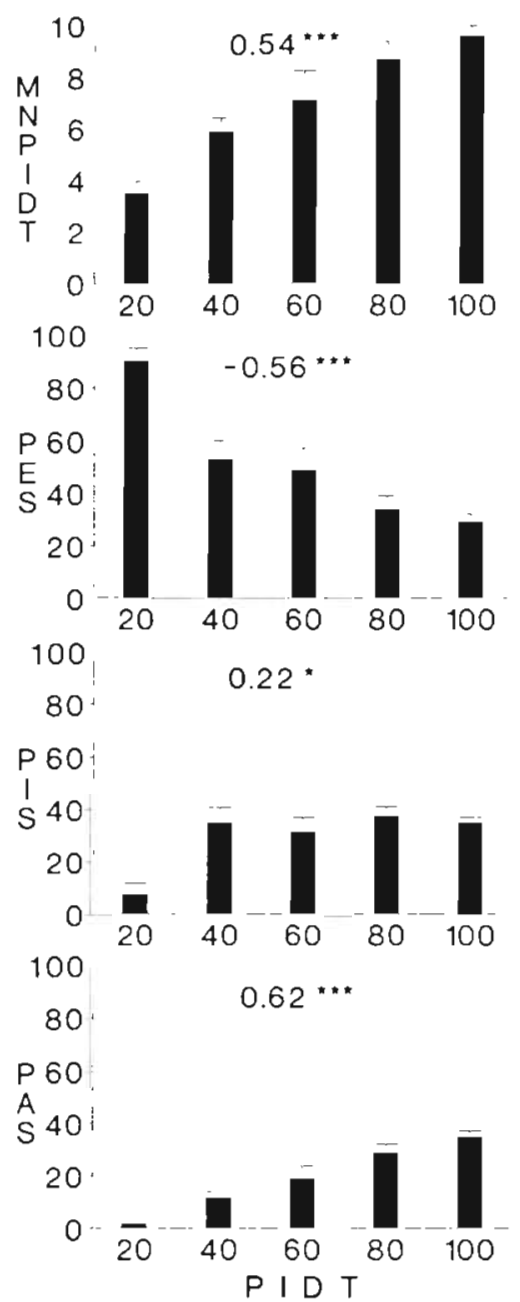

Fig. 12. Mytilus galloprovincialis infected by Marteilia refringens. Variation of the mean no. of parasites per section of infected digestive tubule (MNPIDT), and the percentage of the early, intermediate and advanced stages of sporulation (PES, PIS and PAS respectively) as the infection progresses. The progression is quantified by the percentage of infected digestive tubules (PIDT). PIDTs are grouped in 5 classes. Class marks are the highest values of each class. Height of bars represents the mean value (with standard error) of each variable corresponding to every class of PIDT Sample size was 98 mussels. Numbers at the upper part of each graphic are the values of the Spearman rank correlation coefficients between PIDT and each respective variable. Level of significance of the correlation coefficients: $0.05>p>0.01$;

$$
\cdots p<0.001
$$

showed that both the intensity of hemocytic infiltration and the degree of spreading of granulocytomas were significantly associated with the occurrence of the infection. Differences in the spreading of granulocytomas between infected mussels with different infection intensities were not significant. However, there were some significant differences in hemocytic infiltration between infected mussels with different infection intensities (Tables $4 \& 5$, Fig. 13).

\section{A \\ HEMOCYTIC INFILTRATION CATEGORIES:}

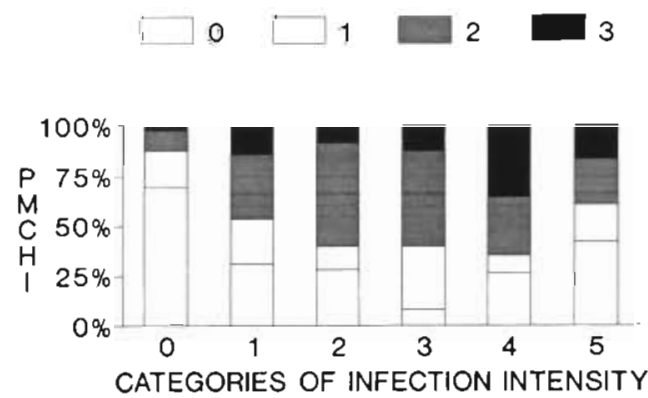

B

GRANULOCYT. SPREADING CATEGORIES:

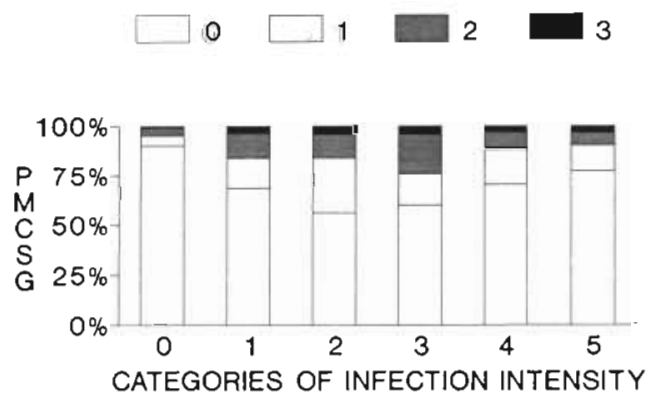

Fig. 13. Mytilus galloprovincialis infected by Marteilia refringens. (A) Distribution of mussels according to intensity of hemocytic infiltration and intensity of infection. PMCHI: Percentage of mussels in each category of hemocytic infiltration. (B) Distribution of mussels according to the spreading of granulocytomas and intensity of infection. PMCSG: Percentage of mussels in each category of spreading of granulocytomas

\section{Spatial and temporal patterns of the infection}

Fig. 14 shows the prevalence and distribution of categories of infection intensity throughout the culture period, in the four zones affected by the disease. No infected mussel was found in samples from Zone 4. The earliest histological evidence of infection was detected in Zones 2 and 3, during the fourth month after introducing the mussel seed. Light and heavy infections (the latter involving sporulation) were detected throughout the year in Zones 1, 2 and 3. Several peaks of both prevalence and occurrence of heavy infections were recorded each year. However, at Zone 5 the infection was only detected in a few monthly samples during the second year of culture, with very low prevalences. Both the prevalence and the infection intensity were higher during the second year of culture except in Zone 1. 
Table 4. Mytilus galloprovincialis infected by Marteilia refringens. Results of $G$-tests for independence to determine whether numbers of mussels in each category of intensity of hemocytic infiltration differ according to intensity of infection. Table shows $G$-values and sample sizes $(n)$ corresponding to the comparisons between each pair of categories of infection intensity; $\mathrm{df}=3$ in every case

\begin{tabular}{|c|c|c|c|c|c|}
\hline $\begin{array}{l}\text { Infection intensity } \\
\text { category }\end{array}$ & 0 & 1 & $\begin{array}{c}\text { n intensity } \\
2\end{array}$ & 3 & 4 \\
\hline 1 & $\begin{array}{l}\mathrm{G}=136.0^{\cdots} \\
\mathrm{n}=1759\end{array}$ & & & & \\
\hline 2 & $\begin{array}{l}G=32.5 \cdots \\
\mathrm{n}=1609\end{array}$ & $\begin{array}{l}G=4.2 \mathrm{~ns} \\
\mathrm{n}=200\end{array}$ & & & \\
\hline 3 & $\begin{array}{l}G=47.9 \cdots \\
\mathrm{n}=1609\end{array}$ & $\begin{array}{l}G=7.6 \mathrm{~ns} \\
\mathrm{n}=200\end{array}$ & $\begin{array}{l}G=5.5 \mathrm{~ns} \\
\mathrm{n}=50\end{array}$ & & \\
\hline 4 & $\begin{array}{l}G=65.7 \cdots \\
\mathrm{n}=1618\end{array}$ & $\begin{array}{l}G=9.9^{\circ} \\
\mathrm{n}=209\end{array}$ & $\begin{array}{l}G=7.2 \mathrm{~ns} \\
\mathrm{n}=59\end{array}$ & $\begin{array}{l}G=11.7^{\cdots} \\
\mathrm{n}=59\end{array}$ & \\
\hline 5 & $\begin{array}{l}G=19.5 \cdots \\
\mathrm{n}=1615\end{array}$ & $\begin{array}{l}G=2.1 \mathrm{~ns} \\
\mathrm{n}=206\end{array}$ & $\begin{array}{l}G=5.3 \mathrm{~ns} \\
\mathrm{n}=56\end{array}$ & $\begin{array}{l}G=10.8^{\circ} \\
\mathrm{n}=56\end{array}$ & $\begin{array}{l}G=5.1 \mathrm{~ns} \\
\mathrm{n}=65\end{array}$ \\
\hline
\end{tabular}

Table 5. Mytilus galloprovincialis infected by Marteilia refringens. Results of G-tests for independence to determine whether numbers of mussels in each category of spreading of granulocytomas differ according to intensity of infection. Table shows G-values and sample sizes (n) corresponding to the comparisons between each pair of categories of infection intensity; $\mathrm{df}=3$ in every case

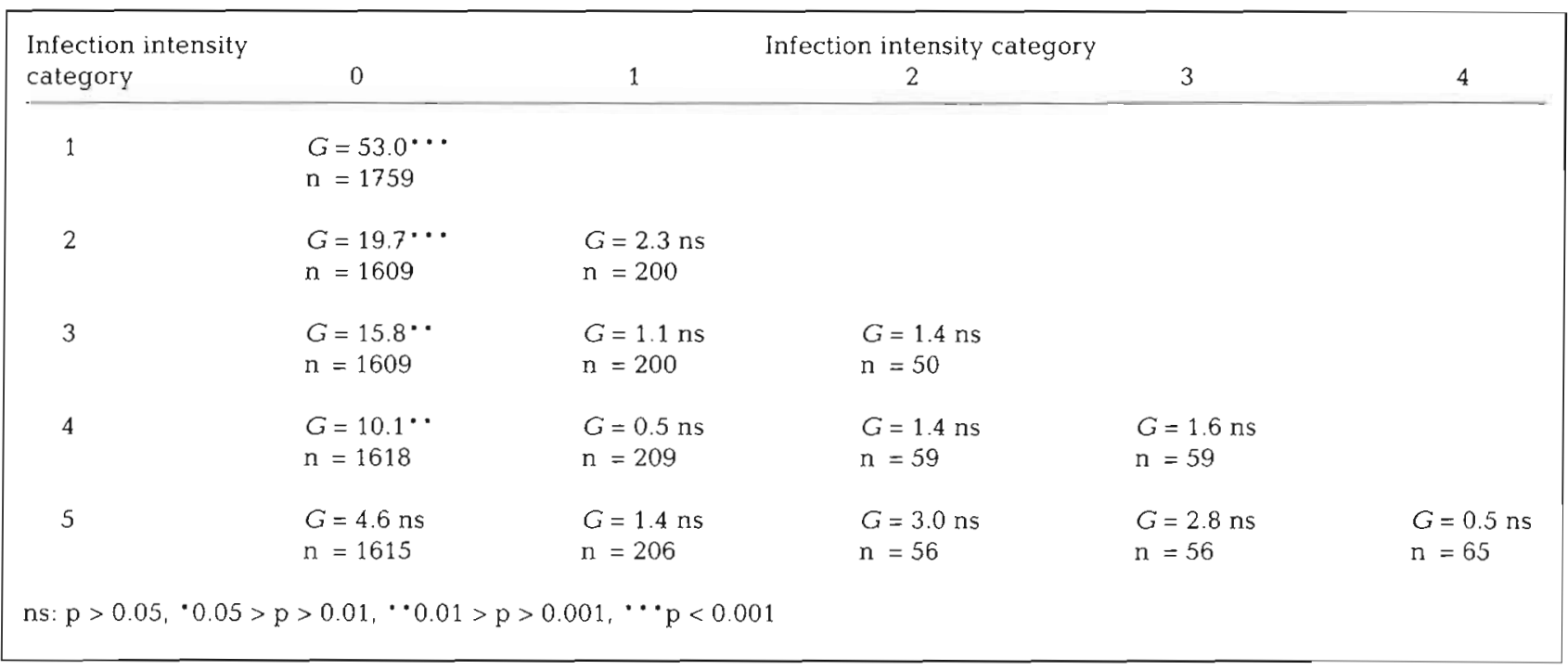

Differences in prevalence among the 4 affected zones were significant in each case except between those recorded at Zones 1 and 2 (Table 6). On the contrary, differences in infection intensity were not significant $(\mathrm{df}=3, G=2.52, \mathrm{p}>0.25)$.

\section{Mortality}

Fig. 15 shows the cumulative mortalities recorded at each zone during a period of 9 to 10 mo. Differences in mussel mortality among culture zones were significant in each case except between those recorded in Zones 2 and 4 (Table 7 ).

\section{DISCUSSION}

\section{Taxonomy}

The process of sporulation of this parasite is characteristic of the phylum Paramyxea (Desportes \& Perkins 

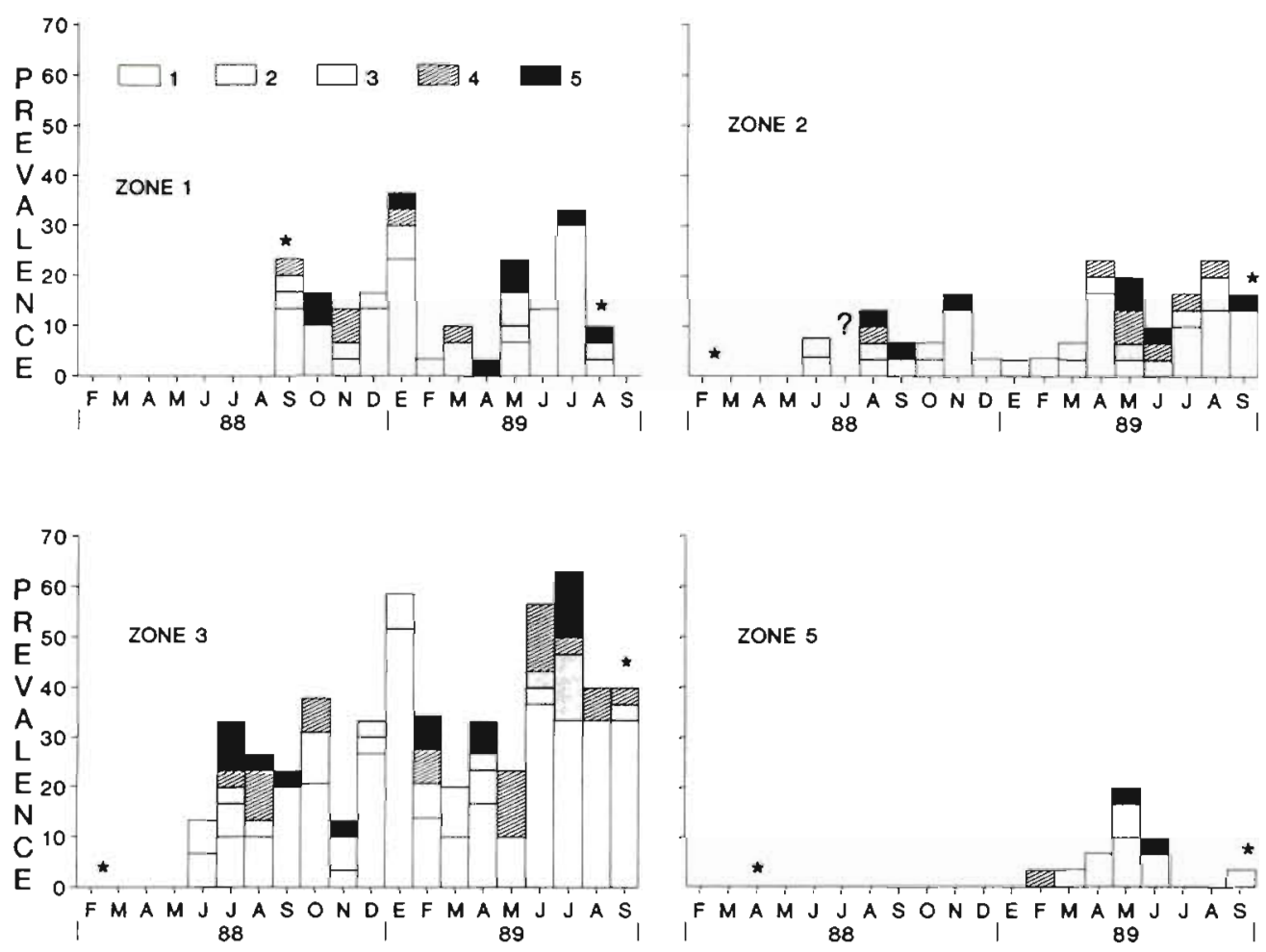

Fig. 14. Marteilia refringens prevalence during the culture period in the zones affected by the disease. $\star$ : beginning and end of experimental cultures; ?: no sample corresponding to July 1988 from Zone 2

1990). The morphological features of the parasite and the histological location of the presporulation and sporulation stages are in agreement with those described by Perkins (1976) for the type species Marteilia refringens, but they also agree with those of $M$. maurini, including the host in this case. The only differences found by Comps et al. (1982) between $M$. maurini and the type species $M$. refringens were their respective

Table 6. Mytilus galloprovincialis infected by Marteilia refringens. Results of $G$-tests to compare the differences in $M$. refringens prevalence between the culture zones affected by the disease. Table shows $G$-values and sample sizes (n) corresponding to the comparisons between each pair of zones; $\mathrm{df}=1$ in every case

\begin{tabular}{|llll|}
\hline & Zone 1 & Zone 2 & Zone 3 \\
\hline Zone 2 & $\begin{array}{l}G=3.8 \mathrm{~ns} \\
\mathrm{n}=715\end{array}$ & & \\
& & & \\
Zone 3 & $\begin{array}{l}G=35.4 \cdots \\
\mathrm{n}=717\end{array}$ & $\begin{array}{l}G=70.0 \cdots \\
\mathrm{n}=712\end{array}$ & \\
& & & \\
Zone 5 & $G=39.7 \cdots$ & $G=19.5 \cdots$ & $G=140.2 \cdots$ \\
& $\mathrm{n}=720$ & $\mathrm{n}=715$ & $\mathrm{n}=717$ \\
ns: $\mathrm{p}>0.05$, & $\cdots \mathrm{p}<0.001$ & & \\
\hline
\end{tabular}

type hosts, the shape of the haplosporosomes of the outer sporoplasm and the structure of the envelope of the spore. The validity of exclusively using these criteria to create a new taxon is doubtful: (1) It is not unusual that some parasitic species are able to infect different bivalve species. For example, controlled introductions of healthy oysters, Ostrea chilensis from

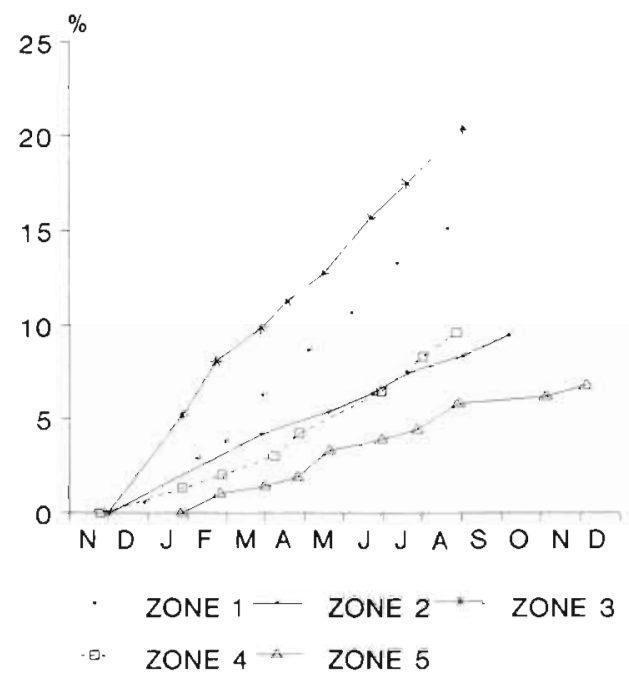

Fig. 15. Mytilus galloprovincialis. Cumulative mortality for each culture zone 
Table 7. Mytilus galloprovincialis infected by Marteilia refringens. Results of $G$-tests to compare the differences in cumulative mortality between the studied culture zones. Table shows $G$-values corresponding to the comparisons between each pair of zones; $d f=1$ and $n=2000$ mussels in every case

\begin{tabular}{|c|c|c|c|c|}
\hline & Zone 1 & Zone 2 & Zone 3 & Zone 4 \\
\hline Zone 2 & \multicolumn{4}{|l|}{$G=23.0^{\cdots}$} \\
\hline Zone 3 & $G=5.4^{\circ}$ & $G=50.3^{\cdots} \cdots$ & & \\
\hline Zone 4 & $G=20.9 \cdots$ & $G=1.0 \mathrm{~ns}$ & \multicolumn{2}{|l|}{$G=47.3^{\cdots} \cdots$} \\
\hline Zone 5 & $G=63.5^{\cdots} \cdots$ & $G=10.5^{\cdots}$ & \multicolumn{2}{|l|}{$G=104.5^{\cdots}$} \\
\hline \multicolumn{5}{|c|}{$n s: p>0.05, \cdot 0.05>p>0.01, \cdots 0.01>p>0.001, \cdots p<0.001$} \\
\hline
\end{tabular}

could be explained by the occurrence of 'vegetative' multiplication (merogony). The merogony would continuously supply new parasites to be involved in sporulation and it would explain the steady increase of the PAS as the infection spreads. The PES initially decreases but later tends to be asymptotic. It could be easily explained by a continuous loss of early stages of sporulation, which evolve to more advanced stages, coupled with an increasing supply of new early stages arising from merogony. Consistently, the PIS remains unchanged as soon as the PIDT

Chile and $O$. angasi from Australia, into areas of the French Atlantic coast where $O$. edulis was naturally infected by $M$. refringens, led to the transmission of the infection to the newly introduced species (Grizel et al. 1983, Bougrier et al. 1986). (2) Comps et al. (1982) noted the occurrence of haplosporosomes with a different shape ( 230 to $320 \times 70$ to $90 \mathrm{~nm}$ ) when describing $M$. maurini. However, there is a certain variability in the shape of these organelles of the outer sporoplasm reported from $M$. refringens: $230 \times 140 \mathrm{~nm}$ (Grizel et al. 1974), 175 to $203 \times 100$ to $130 \mathrm{~nm}$ (Perkins 1976). Auffret \& Poder (1985) noted sizes of $260 \times 120 \mathrm{~nm}$ in M. maurini from the mussel Mytilus edulis. The variability is much greater if the haplosporosomes of the cytoplasm of the primary cell of $M$. refringens are considered (Perkins 1976). (3) Comps et al. (1982) described a layer of concentric membranes surrounding the wall of the mature spore of $M$. maurini which would not occur around the spore of $M$. refringens. However, Perkins \& Wolf (1976) observed a layer of loosely applied whorls around a few spores of $M$. refringens. As a consequence, we choose to include this parasite in the type species, Marteilia refringens, since conclusive evidence to consider the parasite of the mussel as a different species was not found.

The microsporidian Nosema ormieresi is the only protistan hyperparasite reported from any Marteilia species. Comps et al. (1979) found this hyperparasite in $M$. refringens, which was parasitizing Ostrea edulis. The microsporidian-like hyperparasite of our parasite could belong to the same species, but ultrastructural confirmation is lacking.

\section{Progression of the infection in the host}

The pattern of progression of the infection involves that the number of parasites per infected tubule increases as the number of infected tubules becomes higher. It implies an exponential increase of the total number of parasites as the infection progresses, which reaches 20 to $40 \%$. In very heavy infections, in which every digestive tubule is infected with a high number of sporulating parasites, if no merogony occurred, then there would have to be an equal number of infective cells entering the host initially which would then have to each undergo sporulation to yield the observations of such heavy infections. It is much easier to believe that fewer infective stages enter the host, multiply and then undergo sporulation. Nevertheless, Perkins (1988) pointed out that cell multiplication other than in spore formation has not been noted in any Marteilia species. Franc (1980) and Grizel (1985) proposed hypothetical life cycles for $M$. refringens involving schizogony, although definitive evidence was not presented. The observed pattern of progression of the infection shows that the highest PASs occur when the infection reaches the maximum spread (PIDT $=100$ ). It implies the production and release of high numbers of mature spores all at once. It seems to be a strategy of the parasite to insure a succesful propagation. Alderman (1979) also reported similar cases of massive and simultaneous release of spores of $M$. refringens from oysters Ostrea edulis. It seems necessary that some kind of initiator for such wide spreading of the infection occurs. A weak condition of the host could favour the progression of the infection. Moreover, it can be expected that the progression of the infection also contributes to the weakening of the host, since large amounts of parasites inhabit the absorptive epithelia of the digestive tract.

There is evidence that supports a host hemocytic reaction triggered by the infection. Differences in host reaction between infected mussels with different intensity of infection were significant in some cases. This could mean that the host tries to slow down or stop the infection before it becomes widespread by means of a light hemocytic reaction but, if the infection continues spreading, then the host reaction tends to become heavier. Nevertheless, the highest frequency of infected mussels without hemocytic reaction corresponded to the heaviest infections. This could mean that the 
infection spreads the most widely and most quickly when there is no host reaction, but also could mean that the host response is overwhelmed. Figueras et al. (1991) also reported massive hemocytic infiltration into the digestive gland in mussels affected by Marteiliasis from Arousa Bay. Grizel et al. (1974) did not observe hemocytic reaction in oysters Ostrea edulis infected by Marteilia refringens, but Alderman (1979) noted that variable amounts of hemocytic reaction may be observed in the oysters at different stages of the infection.

\section{Spatial and temporal patterns of the infection}

A great spatial variability in the prevalence of Marteiliasis on cultured mussels throughout the bays of Galicia has been found, including a zone in which no infection was detected throughout the whole culture period. Significant differences were detected even between Zones 2 and 3, located in the same bay. In this case, genetic differences in mussel susceptibility to the disease should be discarded, since the mussels cultivated at both places came from the same batch of seed. The zones located in the inner part of the bays (Zones $1 \& 3$ ) had higher prevalences than the zones located in the outer parts (Zones 2, 4 \& 5). In contrast, the percentage of infections that progressed to moderate or heavy categories was similar in each affected zone. The occurrence of an estuarine-oceanic gradient in the prevalence of Marteiliasis on mussel culture was also suggested by Figueras et al. (1991). The lack of infections at Zone 4 does not necessarily imply that Muros Bay is free of Marteiliasis. In fact, Alderman (1979) reported that flat oysters Ostrea edulis cultivated for more than 1 yr in a raft at this bay were free of Marteilia refringens, although there was another raft in which oysters had high burdens of the parasite just $2 \mathrm{~km}$ away, at the same time. Further studies should be carried out on the factors controlling the spatial variability of the incidence of Marteiliasis, since it could have an influence on mussel farming management.

The temporal pattern of the disease at the zones with higher incidence of Marteiliasis indicates that sporulation occurs throughout the year and several peaks of prevalence as well as occurrence of heavy infections take place every year. The latter could coincide with periods of weak condition of the mussels. In fact, the highest percentages of heavy infections coincide with post-spawning periods (Villalba et al. unpubl.). This temporal pattern without a marked seasonality differs from those described for Marteilia refringens in oysters from the French Atlantic coast (Alderman 1979, Balouet et al. 1979, Grizel 1985), since there sporulation takes place during the summer-autumn period, and the winter-spring period is characterized by low prevalences and light infections

\section{Mortality}

Considering the 4 zones affected by Marteiliasis, the higher the observed prevalence of the disease, the higher the observed cumulative mortality, although it is not known what percentage of the mortality can be attributed to Marteiliasis. In an experiment in which 4 different stocks of mussel seed from different localities of Galicia were cultured in each of 3 different areas (inner, intermediate and outer) of Arousa Bay, Fuentes (pers. comm.) also found significantly higher mortalities in the inner area (the same raft as ours at Zone 3) for each mussel stock. By extrapolating from the recorded pattern of cumulative mortality, the expected mortality for a usual culture period (from seed to market size) of 18 mo would be $32 \%$ in Zone $1,17 \%$ in Zone $2,40 \%$ in Zone 3, 18\% in Zone 4 and $12 \%$ in Zone 5 . That is, mortality can attain significant levels in the areas with higher prevalence of this disease.

Heavier mortalities than those recorded in this study could be expected if the prevalence or the intensity of the infection became higher in the mussel culture zones, as occurred with the populations of Ostrea edulis from France and Crassostrea commercialis from Australia affected by Marteilia refringens and $M$. sydneyi, respectively (Alderman 1979, Wolf 1979). Marteiliasis should be considered as a threat to the mussel farming industry of the coast of Galicia.

Acknowledgements. This study could not have been completed without the valuable help of the following mussel farmers: Mr Pedro Caamaño from Muros Bay, Mr Alberto López Saavedra and Mr Jaime Montes from Ares-Betanzos Bay, Mr Armando Otero and Mr José Padín from Arousa Bay and Mr Rouco Caamiña from Vigo Bay. We are grateful to Dr Frank Perkins, Virginia Institute of Marine Science, for his comments on the life cycle and taxonomy of the genus Marteilia. Thanks to Dr José Fuentes for his suggestions on statistical treatment and comments on his experiments on factors controlling the growth rate and survival of the mussels cultivated at Arousa Bay. Thanks to Dr José Molares for his suggestions on statistical treatment. Ms Maribel Meléndez, Ms Teresa Andrade and Ms Elena Penas provided technical assistance for histological technics, Ms Laura Corral for ultrastructural technics, and Mr Joao Carvalheira for iconographic figures. This research was supported by funds of the Ministry of Fisheries and Aquaculture of Galicia. S.G.M. was supported by a FPI scholarship from the Ministry of Education and Science of Spain

\section{LITERATURE CITED}

Alderman, D. J. (1979). Epizootiology of Marteilia refringens in Europe. Mar. Fish. Rev. 41:67-69

Auffret, M., Poder, M. (1985). Recherches sur Marteilia mau- 
rini, parasite de Mytilus edulis sur les côtes de Bretagne Nord. Rev. Trav. Inst. (scient. tech.) Pêch. marit. 47: 105-109

Balouet, G., Chastel, C., Cahour, A., Quillard, A., Poder, M. (1979). Etude épidémiologique et pathologique de la maladie de l'huitre plate en Bretagne. Sci. Pêche 289: $13-23$

Bougrier, S., Tige, G., Bachere, E., Grizel, H. (1986). Ostrea angasi acclimatization to French coasts. Aquaculture 58: $151-154$

Cahour, A. (1979). Marteilia refringens and Crassostrea gigas. Mar. Fish. Rev. 41: 19-20

Comps, M. (1970). Observations sur les causes d'une mortalité anormale des huitres plates dans le bassin de Marennes. Rev. Trav. Inst. (scient. tech.) Pêch. marit. 34: $317-326$

Comps, M. (1976). Marteilia lengehi n. sp. parasite de l'huitre Crassostrea cucullata Born. Rev. Trav. Inst. (scient. tech.) Pèch. marit. 40: 347-349

Comps, M. (1985). Etude morphologique de Marteilia christenseni sp. n. parasite du lavignon Scrobicularia piperata P. (mollusque pélécypode). Rev. Trav. Inst. (scient. tech.) Pêch. marit. 47: 99-104

Comps, M., Joly, J. P. (1980). Contamination expérimentale de Mytilus galloprovincialis Lmk. par Marteilia refringens. Sci. Pêche 301: 19-21

Comps, M., Pichot, Y., Deltreil, J. P. (1979). Mise en evidence d'une microsporidie parasite de Marteilia refringens agent de la maladie de la glande digestive d'Ostrea edulis L. Rev. Trav. Inst. (scient. tech.) Pêch. marit. 43: 409-412

Comps, M., Pichot, Y., Papaqianni, P. (1982). Recherche sur Marteilia maurini n. sp. parasite de la moule Mytilus galloprovincialis Lmk. Rev. Trav. Inst. (scient. tech.) Pêch. marit. 45: 211-214

Comps, M., Grizel, H., Tigé, G., Duthoit, J.-L. (1975). Parasites nouveaux de la glande digestive des mollusques marins Mytilus edulis L. et Cardium edule L. C. r. hebd. Séanc. Acad. Sci., Paris (Sér. D) 281: 179-181

Desportes, I., Perkins, F. O. (1990). Phylum Paramyxea. In: Margulis, L., Corliss, J. O., Melkonian, M., Chapman, D. I. (eds.) Handbook of Protoctista. Jones and Bartlett, Boston, p. $30-35$

Fiqueras, A. J., Jardon, C. F., Caldas, J. R. (1991). Diseases and parasites of rafted mussels (Mytilus galloprovincialis Lmk): preliminary results. Aquaculture 99: 17-33

Franc, A. (1980). Sur quelques aspects inédits du cycle de Marteilia refringens Grizel et coll., 1974, parasite de l'huître plate Ostrea edulis L. Cah. Biol. mar. 21: 99-106
Grizel, H. (1985). Etude des récentes épizooties de l'huitre plate Ostrea edulis Linné et de leur impact sur l'ostréiculture bretonne. Thèse d'Etat, Université de Montpellier

Grizel, H., Comps, M., Bonami, J.-R., Cousserans, F., Duthoit, J. L., Le Pennec, M. A. (1974). Recherche sur l'agent de la maladie de la glande digestive de Ostrea edulis Linné. Sci. Pêche 240: 7-30

Grizel, H., Comps, M., Raguenes, D., Leborne, Y., Tigé, G., Martin, A. G. (1983). Bilan des essais d'acclimatation d'Ostrea chilensis sur les côtes de Bretagne. Rev. Trav. Inst. Pêches marit. 46: 209-225

Gutiérrez, M. (1977a). Nota sobre marteiliasis en el mejillón, Mytilus edulis (L.), de la costa Noroeste de España. Inv. Pesq. 41: 637-642

Gutiérrez, M. (1977b). Técnica de coloración del agente de la enfermedad de la glándula digestiva de la ostra plana, Ostrea edulis L. Inv. Pesq. 41: 643-645

Pérez-Camacho, A., Gonzalez, R., Fuentes, J. (1991). Mussel culture in Galicia. Aquaculture 94: 263-278

Perkins, F. O. (1976). Ultrastructure of sporulation in the European flat oyster pathogen, Marteilia refringens Taxonomic implications. J. Protozool. 23:64-74

Perkins, F. O. (1988). Structure of protistan parasites found in bivalve molluscs. Am. Fish. Soc. (Spec. Publ.) 18: 93-111

Perkins, F. O., Wolf, P. H. (1976). Fine structure of Marteilia sydneyi n. sp. - haplosporidian pathogen of Australian oysters. J. Parasitol. 62: 528-538

Poder, M., Auffret, M., Balouet, G. (1983). Etudes pathologiques et épidémiologiques des lésions parasitaires chez Ostrea edulis L. Premiers résultats d'une recherche prospective comparative chez les principales espèces de mollusques des zones ostréicoles de Bretagne Nord. In: Colloques sur les bases biologiques de l'aquaculture, Dec. 12-16, 1983. CNRS-CNEXO, Montpellier, p. $125-138$

Sokal, R. R., Rohlf, F. J. (1981). Biometry, 2nd edn. W. H. Freeman \& Co., San Francisco

Steel, R. G. D., Torrie, J. H. (1980). Principles and procedures of statistics. A biometrical approach, 2nd edn. McGrawHill Book Co., New York

Tigé, G., Rabouin, M. A. (1976). Etude d'un lot de moules transférées dans un centre touché par l'épizootie affectant l'huitre plate. Comm. Meet. int. Coun. Explor. Sea C.M.ICES/K: 21

Wolf, P. H. (1979). Life cycle and ecology of Marteilia sydneyi in the Australian oyster, Crassostrea commercialis. Mar. Fish. Rev. 41: 70-72

Manuscript first received: December 28, 1992

Revised version accepted: March 18, 1993 